The Canadian Journal of Higher Education, Vol. XXV-3, 1995

La revue canadienne d'enseignement supérieur, Vol. XXV-3, 1995

\title{
Conceptualizing Academic Library Use: Results of a Survey of Continuing Education Students in a Small Canadian Undergraduate University
}

\author{
A. PAUL WILLIAMS*
}

\section{Abstract}

This paper analyzes data from a survey of 4,084 continuing education students in a small Canadian undergraduate university to document and conceptualize patterns of library services use and factors influencing use. Factor analysis, multiple regression and analysis of variance are employed to examine the impact of three sets of explanatory variables on academic library use: student characteristics (e.g., age, sex and previous education); perceptions of problems limiting library use; (e.g., the adequacy of the collection, hours, and access to materials); and characteristics of the student's program of study (e.g., field of study, type of program, number of library-related assignments). The findings show that the most frequently used university library services, accounting for almost half of all use, were the study areas and the photocopy machines. The characteristics of the student's program of study including the extent to which library use was integrated into assignments and classroom discussion was found to be a strong predictor of use. The paper concludes that when conceptualizing and planning library services greater attention must be given to the broader learning environment of which the library is part and to the characteristics and needs of increasingly diverse student populations.

* Associate Professor, Department of Health Administration, University of Toronto, Toronto, Canada. The author gratefully acknowledges the valuable advice and support of Miriam Atkin, Liz Bishop, Milton Orris, Daniel Phelan and Lorraine Wilson. 


\section{Résumé}

L'auteur examine les résultats d'un sondage auquel ont participé 4084 étudiants inscrits à des programmes d'éducation permanente dans une petite université canadienne offrant exclusivement des études de premier cycle. Ce sondage avait pour but de documenter les habitudes des étudiants sur le plan de leur utilisation des services fournis par la bibliothèque, en vue de conceptualiser cette utilisation et d'en déterminer les principaux facteurs. L'auteur a recours à l'analyse factorielle, à l'analyse par régression multiple et à l'analyse de la variance comme méthodes pour étudier les effets de trois ensembles de variables permettant d'expliquer l'utilisation de la bibliothèque universitaire, à savoir: caractéristiques des étudiants (p. ex., âge, sexe, et scolarité); perceptions des problèmes pouvant limiter l'utilisation de la bibliothèque ( $p$. ex., suffisance de la collection, heures d'ouverture, accès aux documents); particularités du programme d'études suivi part l'étudiant (p. ex., domaine d'études, type de programme, nombre de travaux exigeant la fréquentation de la bibliothèque). Les résultats du sondage indiquent que les aires d'études et les photocopieurs figuraient parmi les services les plus utilisés à la bibliothèque, ce qui correspond à environ la moitié du temps d'utilisation de ceux-ci. Les particularités du programme d'études suivi par l'étudiant, y compris le nombre de travaux et de discussions en classe nécessitant la fréquentation de la bibliothèque, constituaient un important élément de prédiction relativement à l'utilisation. À titre do conclusion, l'auteur indique que, pour conceptualiser et planifier des services de bibliothèque, il faut accorder plus d'importance au milieu d'apprentissage global, duquel la bibliothèque fait notamment partie, ainsi qu'aux caractéristiques et aux besoins d'une population étudiante de plus en plus variée.

\section{Introduction}

When asked why he robbed banks, Willie Sutton is said to have replied "because that's where the money is." Academic libraries and patterns of library use have often been addressed in much the same way: students use libraries because that's where the books are. Just as banks can be viewed primarily as repositories of cash, academic libraries are seen primarily as collections of books. However, this logic overlooks the complex and rapidly changing context in which both banks and academic libraries exist and the range of factors which influence use, key among them, user needs. Instead of finding out more about 
what motivates Willie Sutton to rob banks, or students to use libraries, we ask how much the banks and libraries hold.

This paper analyzes data from a survey of continuing education students in a small Canadian undergraduate university to document and conceptualize patterns of library use and factors influencing use. It starts from the assumption that academic libraries, and the universities of which they are a part, exist to serve the needs of students and not the reverse. However, in spite of frequent exhortations in the literature to systematically evaluate student needs as the basis for planning academic services including library services (Berry, 1985; Schlachter \& Belli, 1976; Schlichter \& Pemberton, 1992), there is relatively little information which documents the library needs of Canadian university students. Particularly little is known about the needs of the growing number of students who are not in traditional full-time undergraduate studies; in 1994 there were 335,000 students enrolled in continuing education courses at Canadian universities (Statistics Canada, 1994).

The paucity of systematic data about user needs reflects an historically dominant view of academic library as collection. A particularly good statement of this view is found in Miksa's comments (1989) to an international session on the future of academic research libraries. Miksa observes that the collection has conventionally been the focus of the library: "all else, although not unimportant, simply follows from it; all else is derivative; all else is peripheral" (p. 781). Thus the academic research library has been judged "first of all" by the size of its collection and by the number of unique holdings in specialized fields. The collection as beginning point also conditions views of user needs which tend to be defined as a function of the library collection. While library holdings are categorized, catalogued and evaluated, users remain "relatively anonymous, a more or less undifferentiated mass of persons or set of amorphous groups" (Miksa, 1989, p. 783). At best users are categorized into generic groups such as undergraduates, graduates, academics and staff (Miksa, 1989).

There are, however, increasing pressures to change how the library is conceptualized and planned. Among other developments, the enormous increase in the volume of information available, a shift to problem-based, multi-disciplinary learning and research, and the widespread use of computer-based technologies to access remote data bases suggest a revolution "which pivots on achieving specificity, on tailoring information retrieval to the specific information requirements of users" (Miksa, 1989, p. 785). As opposed to the conventional focus on the library collection, this perspective draws attention to the needs of library users and to assisting users in "interpreting, applying, manipulating and producing information," whether or not the information is or will 
ever be part of the collection (p. 786). By shifting to a user- as opposed to collection-based conceptualization of the library, meeting user information needs becomes the central purpose of library work; building the collection is only one and perhaps not even the most important means of addressing such needs.

As responses to Miksa's comments indicate (Brody, 1989; Kopplin, 1989; Malone, 1989), this critical vision of the academic library is not universally shared: there remains the view that the collection is still the heart of the library, a key resource for doing exactly what Miksa suggests, responding to user needs. Nevertheless, Miksa's comments focus attention on what users require, as well as on what libraries provide, and suggest that evaluation of the academic library must go beyond simply documenting the extent of library holdings and services to analysing the characteristics and needs of users within the context of their broader learning environment.

A major aim of this paper is to contribute to a more developed conceptual understanding of multiple factors which influence academic library use. As the literature suggests (Berry, 1985; Schlachter \& Belli, 1976; Schlichter \& Pemberton, 1992), such an understanding is an important prerequisite for planning the future of library services in a rapidly changing environment. Libraries, like organizations in other sectors, particularly those supported by public funds, are increasingly required to justify their services in terms of consumer needs (Schlichter \& Pemberton, 1992). A second related aim is to focus attention on the particular characteristics and needs of continuing education (CE) students who, in spite of their numbers (Statistics Canada, 1994) and economic importance to cash-strapped universities, are not accorded the status or attention given to students in mainstream academic departments and schools.

In addition to documenting patterns of library use, this paper examines the extent of the statistical association between patterns of use and three sets of explanatory variables measuring:

- the characteristics of individual students (including age, sex and previous education)

- perceptions of problems limiting library use (including the adequacy of the collection and scheduled hours); and

- the characteristics of the student's academic program (including field of study and program type).

The analysis thus explicitly tests the hypothesis that patterns of library use are related to multiple factors and conditions which extend beyond the library itself, to include the characteristics of students and their broader learning environments (Zweizig, 1976). 


\section{Methods}

The survey reported in this paper was conducted at a small Canadian undergraduate university which maintains a strong focus on applied professional education in business, community services, engineering and technology, and applied arts. This university is located in a major metropolitan area with access to numerous public libraries, a central reference library, government and private libraries, and academic libraries attached to six post-secondary institutions including the one in this study. The library collection at this university included about 500,000 items, the majority of which were books and periodicals. The library's use of computers began in the late 1970's when it was one of the first academic libraries in Canada to introduce computerized bibliographic systems.

At the time of the survey, this university had approximately $20,000 \mathrm{stu}-$ dents enrolled in full- and part-time degree programs offered through mainstream academic departments and schools like nursing and business; depending on the program, full-time students typically took between five and seven half courses per semester. The university also had 42,000 individual course registrations per year from a growing and culturally diverse Continuing Education student population. Although the Division of Continuing Education is not considered a mainstream academic unit at this university, a majority of CE registrations were in courses credited as part of certificate or degree programs. As documented by the results of unpublished in-house surveys, there was wide variation in the motivations and personal characteristics (e.g., age, gender, previous professional and educational experience) of $\mathrm{CE}$ students but a majority were female, adult learners, employed outside of the home, returning to school to upgrade their educational credentials for personal and job-related reasons. This contrasts to more "traditional" students who typically enter undergraduate programs directly from high school and who, as a result, tend to be younger and, in most cases, aiming to establish rather than enhance, careers.

The survey was designed in close collaboration with librarians, continuing education program directors and the continuing education students' association. The theoretical survey population consisted of all students taking courses through the Division of Continuing Education during the 1991-92 academic year. By contrast, the empirical survey sample included only those CE students taking courses during the 1992 Winter (January to April) semester. Although CE course offerings varied to some extent from semester to semester, program directors and student association leaders felt that the courses offered during this period, and the students enrolled in them, would constitute fair representations of CE offerings more generally, and the broader CE student population. 
A pilot survey was conducted during the Fall 1991 semester and revisions to the survey content and method were made as a result. The full-scale survey was conducted during a two week period in March 1992. This period was selected because it was toward the end of the semester, thus allowing students to report on their library use during the semester without overlapping final examinations. Closed-ended questionnaires were delivered by hand to each of 218 evening classes running during the survey period (exact question wordings are given in Appendix A). This number included most but not all of the classes scheduled on campus: 18 classes had apparently changed location and could not be found, and in 32 cases instructors refused to allow the survey to be administered. However, subsequent analysis failed to reveal any systematic pattern of non-response at this level; "lost" classes and refusals were not concentrated in any particular program or field of study. Of the estimated 5,000 students attending CE classes during the survey period, 4,084 completed and returned usable questionnaires for a response rate of greater than $80 \%$. Although university registration records were not set up in a way which would permit us to directly confirm the representativeness of the respondents, the results were compared against those of the unpublished in-house surveys noted above; these comparisons failed to reveal any systematic response/non-response bias in age, sex, field of study or program type. The sheer size of the sample and the high response rate together generate confidence that the survey responses are representative of the broader CE student population.

A particular characteristic of this sample is worth noting. Although the survey was aimed at continuing education students, just over $12 \%$ of those surveyed indicated that they were registered in full-time programs. At this university, as at others, the intermixing of "evening" and "day" students has become increasingly prevalent. Growing numbers of part-time continuing education "evening" students are now attempting to complete their studies on a "fast track" basis by taking additional courses during the day while more fulltime "day" students, because of jobs, families and other responsibilities are seeking to manage busy schedules by attending evening classes. The result is that the conventional distinction between continuing education and traditional students is being eroded.

Some methodological notes are in order. Crosstabulations are used to show overall distributions of library use by the three groups of explanatory variables measuring student characteristics, perceptions of problems limiting library use, and student's program of study. To simplify presentation, use estimates in the crosstabulations are recoded into three self-explanatory categories: "no use," "1-10 uses," and "10+ uses." However, the tables also include estimates of 
"average number of uses" calculated prior to recoding the data into these three categories. The eta statistics in the tables are computed not on the recoded data in the crosstabulations but on these averages (means); they measure differences of means between categories of respondents (e.g., females compared to males) in the analysis.

As detailed in Appendix B confirmatory factor analysis was used to construct a multiple-item summary measure of frequency of use of university library services. Multiple regression and analysis of variance are used to examine the statistical association between this continuous multiple item measure and the three groups of explanatory variables: student characteristics, perceptions of problems limiting library use and student's program of study. Categorical explanatory variables are dealt with in the regressions through the use of dummy variables.

\section{Findings}

\section{Patterns of Library Use}

The data in Table 1 describe overall patterns of library use for all students surveyed. Note that library use as defined in this table is not limited to use of the university library alone; community library use is also measured. These data show that about one in ten of the respondents used only the university library (10.9\%) during the semester, a slightly larger proportion (14.1\%) used only community libraries, while about a third $(38.7 \%)$ used both university and community libraries. The remaining third (36.3\%) used no library services during the semester.

The survey asked students to indicate how frequently they had used each of nine major library services. The results in Table 2 show that "study areas" were the most frequently used service: $47.5 \%$ of all respondents used the study areas

Table 1

Overall Patterns of Library Use and Non-use

\begin{tabular}{lcc}
\hline Library Use & Number of Students & Percent of Students \\
\hline No Library Use & 1392 & $36.3 \%$ \\
University Library Only & 541 & 10.9 \\
Other Library Only & 417 & 14.1 \\
Both Used & 1485 & 38.7 \\
Total & 3835 & $100.0 \%$ \\
\hline
\end{tabular}


Table 2

Patterns of University Library Services Use

\begin{tabular}{lcccc}
\hline & \multicolumn{4}{c}{ Number of Uses } \\
\cline { 2 - 5 } Service Used & No Use & $1-10$ Uses & 10+ Uses & $\begin{array}{c}\text { Average } \\
\text { No. of Uses }\end{array}$ \\
\hline Study Areas & $37.7 \%$ & $47.5 \%$ & $14.8 \%$ & 2.0 \\
Photocopier & 48.1 & 39.5 & 12.3 & 1.7 \\
Borrowing Books & 52.7 & 39.0 & 8.3 & 1.4 \\
Periodicals & 54.0 & 41.1 & 5.9 & 1.2 \\
Staff Assistance & 54.5 & 42.6 & 2.9 & 0.9 \\
Reserve Collection & 74.0 & 23.4 & 2.6 & 0.5 \\
Total Uses & & & & 7.6 \\
\end{tabular}

between 1 and 10 times, and $14.8 \%$ used them more often corresponding to an overall average of 2.0 or two uses per student per semester. The next most frequently used library service was the xerox machine which was used by over half of all students (51.8\%) for an average of 1.7 uses per semester. By comparison, less than half of the students $(47.3 \%$ ) had used the library collection for an average of 1.4 uses per semester. Periodicals ranked next with an average of 1.2 uses, followed by staff assistance (.9 uses) and the reserve collection (.5 uses). Other services such as the audio-visual collection, CD ROM and inter-library loans averaged less than .3 uses per semester and are not presented in the table.

\section{Factors Influencing University Library Use}

Student Characteristics. Table 3 presents crosstabulations by key student characteristics of the multiple item summary measure of the six most frequently used university library services. The figures in the table reveal only marginal gender differences in the total number of services used: just over half of women and men $(54.0 \%$ and $52.3 \%$ ) used no university library services at all, $21.9 \%$ of women compared to $25.0 \%$ of men used the six services between 1 and 10 times, while $24.1 \%$ and $22.7 \%$ of women and men used them more often. Average total use estimates are 7.5 for women and 7.2 for men, a difference which is not statistically significant.

There is a small but statistically significant difference in total university library services use associated with student's first language. Students whose first language was English averaged 6.9 uses during the semester; students 
Table 3

Total University Library Services Use By Student Characteristics

\begin{tabular}{|c|c|c|c|c|c|c|}
\hline \multirow[b]{2}{*}{ Learner Characteristic } & \multicolumn{6}{|c|}{ Number of Uses } \\
\hline & No Use & $1-10$ Uses & $10+$ Uses & $\begin{array}{c}\text { Average } \\
\text { Total Use } \dagger\end{array}$ & Eta $\ddagger$ & $\begin{array}{l}\text { Percent } \\
\text { of Cases }\end{array}$ \\
\hline \multicolumn{7}{|l|}{ Gender } \\
\hline Female & $54.0 \%$ & $21.9 \%$ & $24.1 \%$ & 7.5 & & $55.9 \%$ \\
\hline Male & 52.3 & 25.0 & 22.7 & 7.2 & .00 & 44.1 \\
\hline \multicolumn{7}{|l|}{ First Language } \\
\hline English & 54.7 & 23.2 & 22.1 & 6.9 & & 67.5 \\
\hline Other & 50.1 & 23.2 & 26.7 & 8.5 & $.06^{* *}$ & 32.5 \\
\hline \multicolumn{7}{|l|}{ Prior Education } \\
\hline High School & 43.9 & 21.9 & 34.2 & 10.9 & & 33.5 \\
\hline Diploma & 52.4 & 25.0 & 22.6 & 7.2 & & 34.1 \\
\hline Degree & 61.9 & 22.7 & 15.4 & 4.6 & $.20^{* *}$ & 32.5 \\
\hline \multicolumn{7}{|l|}{ Age } \\
\hline $19-29$ & 47.8 & 22.8 & 29.4 & 9.3 & & 57.0 \\
\hline $30-39$ & 61.0 & 23.7 & 15.3 & 4.9 & & 29.9 \\
\hline $40-49$ & 55.8 & 24.0 & 20.2 & 6.1 & $.15^{* *}$ & 13.1 \\
\hline \multicolumn{7}{|l|}{${ }^{* *} \mathrm{p} \leq .01$} \\
\hline \multicolumn{7}{|c|}{$\begin{array}{l}\dagger \text { Calculated by summing and then averaging each respondent's use of study areas, photocopier, } \\
\text { borrowing books, periodicals, staff assistance, and reserve collection. For details, see Appendix B. } \\
\ddagger \text { Measurement of the statistical relation between interval and categorical variables. Ranges from } \\
0 \text { to l, with higher scores indicating stronger relations. }\end{array}$} \\
\hline
\end{tabular}

whose first language was not English averaged 8.5 uses. Differences related to previous education are also significant: students with only high school education prior to taking continuing education courses averaged 10.9 uses compared to 7.2 for those who had previously completed a college diploma and 4.6 for those with an undergraduate degree. Differences in library use were also related to the student's age: compared to students over the age of 30, those between 19 and 29 used library services significantly more often.

Program Characteristics. Table 4 reveals a strong pattern of statistical association between total use of university library services and the characteristics of the student's academic program. For instance, two thirds of those registered in individual courses $(66.7 \%)$ and about the same proportion taking courses as part of non-degree certificate programs $(63.8 \%)$ reported that they 
Table 4

Total University Library Services Use By Program Characteristics

\begin{tabular}{|c|c|c|c|c|c|c|}
\hline \multirow[b]{2}{*}{ Program Characteristic } & \multicolumn{6}{|c|}{ Number of Uses } \\
\hline & No Use & 1 - 10 Uses & $10+$ Uses & $\begin{array}{l}\text { Average } \\
\text { Total Use }\end{array}$ & Eta & $\begin{array}{l}\text { Percent } \\
\text { of Cases }\end{array}$ \\
\hline \multicolumn{7}{|l|}{ Program type } \\
\hline Courses only & $66.7 \%$ & $20.3 \%$ & $13.0 \%$ & 4.0 & & $21.0 \%$ \\
\hline Certificate & 63.8 & 24.0 & 12.2 & 3.8 & & 47.9 \\
\hline P.T. Degree & 41.1 & 29.4 & 29.5 & 8.8 & & 18.4 \\
\hline F.T. Degree & 8.7 & 15.6 & 75.7 & 25.0 & $.54 * *$ & 12.7 \\
\hline \multicolumn{7}{|l|}{ Field of Study } \\
\hline Arts & 48.5 & 27.1 & 24.4 & 7.6 & & 14.2 \\
\hline Applied Arts & 54.3 & 22.5 & 23.2 & 7.8 & & 15.0 \\
\hline Business & 56.3 & 23.1 & 20.6 & 6.3 & & 51.3 \\
\hline Community Services & 38.9 & 27.3 & 33.8 & 12.2 & & 5.2 \\
\hline Engineering, Tech. & 47.5 & 18.8 & 33.7 & 10.6 & $.14^{* *}$ & 14.2 \\
\hline \multicolumn{7}{|l|}{ Library Use Required } \\
\hline Yes & 44.3 & 26.2 & 29.5 & 9.2 & & 60.0 \\
\hline No & 65.4 & 18.5 & 16.1 & 5.2 & $.15^{* *}$ & 40.0 \\
\hline \multicolumn{7}{|l|}{ Had Orientation } \\
\hline Yes & 33.6 & 25.5 & 40.9 & 13.2 & & 26.2 \\
\hline No & 60.0 & 22.2 & 17.8 & 5.6 & $.26 * *$ & 73.6 \\
\hline \multicolumn{7}{|l|}{ Library Discussed } \\
\hline Yes & 37.6 & 30.1 & 32.3 & 10.4 & & 68.8 \\
\hline No & 59.6 & 20.1 & 20.3 & 6.3 & $.14^{* *}$ & 31.2 \\
\hline
\end{tabular}

had used no university library services during the semester; $41.1 \%$ of those enrolled in part-time degree programs but only $8.7 \%$ of those registered in fulltime degree programs reported no library use. The corresponding average use estimates emphasize the extent of these differences: part-time degree students averaged 8.8 services per semester, a figure more than double the number for those enrolled in single courses (4.0) or non-degree certificates (3.8), but only a third as large as the average (25.0) for full-time degree students.

Field of study was also significantly associated with overall university library use. Students in Community Services (including nursing, social work, nutrition and child and youth care) averaged 12.2 uses. In contrast, Business students used the library least frequently, 6.3 times, or about half as often. 
Students in Arts courses (including economics, history, philosophy, politics, psychology and sociology) and Applied Arts (e.g., publishing, graphic design, journalism, dance and theatre) averaged just under eight uses.

Three additional aspects of the student's program of study are also related to library use. Students in courses which required research and reading outside of course lectures reported significantly higher rates of use than those in courses which did not involve such requirements (9.2 versus 5.6 uses respectively). Students who received a formal orientation to library services reported rates of use more than double those of students who did not have such an orientation (13.2 versus 5.6). Finally, students whose course instructors had discussed use of library services in connection with course work also used significantly more library services than others (10.4 versus 6.3).

Perceptions of Problems Limiting Library Use. The survey also asked students to assess a number of perceived university library characteristics as problems limiting their use; these characteristics had been identified in the pilot survey. The data in Table 5 show that $17.9 \%$ and $36.6 \%$ respectively judged an "inadequate collection" as a "very limiting" or "limiting" problem. Interestingly, individuals with lower levels of library use were less likely to perceive the collection as a problem. A similar pattern is observed for the next 4 variables in the table: "materials locked and inaccessible in evenings and on weekends," "inappropriate hours," "lack of library staff" and "don't know how to use the library." In each case about half of the respondents judged these as "limiting" or "very limiting" problems $(56.5 \%, 51.9 \%, 48.8 \%$ and $47.3 \%$ respectively). Also in each case students who used the library most frequently were most likely, and those who used the library least were least likely, to perceive them as problems limiting library use.

Responses to the last item in the table reveal an opposite pattern. A majority of respondents $(65.6 \%)$ assessed "don't know how to get a library card" as a problem "not limiting" their library use. However, in this case, those who used the library least were most likely to see this factor as "limiting" or "very limiting" with respect to their library use.

Multivariate Analysis. Results of the multiple regressions and analysis of variance are presented in Table 6 . They show that when entered into the regressions without controlling other variables, student characteristics (gender, first language, prior education and age) alone accounted for $5 \%$ of the variance in total library services use; program characteristics (including program type and field of study) alone accounted for $33 \%$ of the variance; and perceptions of factors limiting use alone accounted for $11 \%$. 
Table 5

Total University Library Services Use By Perceptions of Problems Limiting Use

\begin{tabular}{|c|c|c|c|c|c|c|}
\hline \multirow[b]{2}{*}{ Problems } & \multicolumn{6}{|c|}{ Number of Uses } \\
\hline & No Use & $1-10$ Uses & $10+$ Uses & $\begin{array}{l}\text { Average } \\
\text { Total Use }\end{array}$ & Eta & $\begin{array}{l}\text { Percent } \\
\text { of Cases }\end{array}$ \\
\hline \multicolumn{7}{|c|}{ Inadequate Collection } \\
\hline Not Limiting & $50.0 \%$ & $27.7 \%$ & $22.3 \%$ & 7.2 & & $45.6 \%$ \\
\hline Limiting & 41.0 & 26.2 & 32.8 & 10.0 & & 36.6 \\
\hline Very Limiting & 48.7 & 21.4 & 29.9 & 9.9 & $.10^{* *}$ & 17.9 \\
\hline \multicolumn{7}{|c|}{ Limited Weekend Access } \\
\hline Not Limiting & 60.2 & 26.6 & 13.2 & 4.5 & & 43.4 \\
\hline Limiting & 37.9 & 26.0 & 36.1 & 11.0 & & 40.5 \\
\hline Very Limiting & 31.1 & 24.4 & 44.5 & 14.2 & $.28 * *$ & 16.0 \\
\hline \multicolumn{7}{|l|}{ Library Hours } \\
\hline Not Limiting & 51.0 & 28.7 & 20.3 & 6.7 & & 48.2 \\
\hline Limiting & 40.2 & 25.7 & 34.1 & 10.3 & & 38.4 \\
\hline Very Limiting & 47.0 & 18.8 & 34.2 & 11.1 & $.14 * *$ & 13.5 \\
\hline \multicolumn{7}{|l|}{ Lack of Staff } \\
\hline Not Limiting & 56.0 & 25.3 & 18.7 & 5.9 & & 51.2 \\
\hline Limiting & 37.9 & 27.1 & 35.0 & 10.8 & & 42.9 \\
\hline Very Limiting & 33.2 & 21.2 & 45.6 & 15.6 & $.22 * *$ & 5.9 \\
\hline \multicolumn{7}{|l|}{$\begin{array}{l}\text { Don't Know How } \\
\text { to Use Library }\end{array}$} \\
\hline Not Limiting & 53.8 & 23.5 & 22.7 & 7.4 & & 52.7 \\
\hline Limiting & 40.0 & 29.1 & 30.9 & 9.3 & & 39.1 \\
\hline Very Limiting & 53.9 & 19.7 & 26.4 & 8.4 & $.06 * *$ & 8.2 \\
\hline \multicolumn{7}{|l|}{$\begin{array}{l}\text { Don't Know How } \\
\text { to Get Card }\end{array}$} \\
\hline Not Limiting & 42.6 & 27.5 & 29.9 & 9.4 & & 65.6 \\
\hline Limiting & 51.9 & 24.8 & 23.3 & 7.2 & & 24.4 \\
\hline Very Limiting & 64.1 & 17.8 & 18.1 & 6.4 & $.09 * *$ & 10.1 \\
\hline$* * \mathrm{p} \leq .01$ & & & & & & \\
\hline
\end{tabular}


Table 6

Analysis of Variance for Multiple Regressions of Learner Characteristics, Program Characteristics and Problems Limiting Use on Total University Library Services Use

Variance Explained $\left(\mathrm{R}^{2}\right)$

Explanatory Variables $\quad$ Zero Order Estimates $\dagger \quad$ Controlled Estimates $\ddagger$

Learner Characteristics

Program Characteristics

Problems Limiting Use

Total $\mathrm{R}^{2}$
$.05 * *$

$.33 * *$

$.11 * *$

$.36 * *$
$.01 * *$

$.20 * *$

$.02 * *$

$.36^{* *}$

$* * \mathrm{p} \leq .01$

$\dagger$ Estimates are not controlled for other groups of explanatory variables; e.g. estimates measure the impact of learner characteristics on total university library use when they are entered into the regressions alone.

‡ Estimates are controlled for other groups of explanatory variables; e.g. estimates measure the impact of learner characteristics on total university library use after the independent effects of program characteristics and problems limiting use are statistically controlled.

When the 3 groups of explanatory variables were entered simultaneously into the regressions, the "zero-order" variance estimates measuring the explanatory power of student characteristics, program characteristics, and perceptions of the library declined but remained statistically significant. For instance, when program characteristics and perceptions of problems limiting use were controlled, student characteristics accounted for only $1 \%$ of the variance. Similarly, when student characteristics and perceptions of problems limiting use were controlled, program characteristics accounted for only $20 \%$ of the variance; and when student characteristics and program characteristics were controlled, perceptions of problems limiting use accounted for $2 \%$. The $\mathrm{R}^{2}$ estimating the total variance explained in the regressions by the three groups of explanatory variables was .36 or $36 \%$.

\section{Discussion}

The survey data document patterns of library use among continuing education students at a small Canadian undergraduate university. In doing so they contribute to a conceptual understanding of the university library and the multiple factors which influence its use. 
The data suggest, first of all, that at least from a student perspective, library use should be seen to involve more than just use of the university library and its collection. While this may seem self-evident, there have been too few attempts to situate the university library within the broader learning environment and needs of the user. This has important consequences. Too narrow a focus on the university library ignores the fact that many students, including more than half of the survey respondents, use other libraries located around the university or around their jobs and homes. A narrow focus also reinforces a too frequently heard suggestion that students just aren't interested or motivated since many don't use the university library although, as the data show, most used community libraries in conjunction with, or to the exclusion of, the university library. Such a focus also mitigates against asking key questions about the role of the academic library and its contribution to meeting student needs within the context of access to multiple other libraries and information resources. Such questions become particularly important with the expansion of the electronic information "highway" and the ability to remotely access information systems as well as programs of education across the world. In the future, even more than now, students will not need to rely on university libraries or on universities themselves just because they are close by; they will use them because they serve their needs.

What do these data suggest about the role of the university library in meeting the needs of continuing education students? A simplistic interpretation would be that because xerox machines and study areas are the most frequently used services, accounting for half of all library use by survey respondents, that the library collection is of secondary importance and that the library itself is being transformed into a convenient, if expensive, copy shop. Such an interpretation could be used to justify cuts to acquisition budgets during periods of fiscal restraint. This interpretation also plays on the unjustified and inaccurate image of the continuing education student as academically inferior. Reflecting Miksa's (1989) comments cited earlier in this paper, a more useful approach might be to recognize the importance of xerox machines and study areas as tools for accessing and manipulating library information resources including the collection. From a user perspective, particularly from the perspective of the continuing education student who typically has less time on campus and less access to student services which are often scheduled around day programs, the xerox machine and study areas may constitute learning resources no less important than the collection.

Further, the survey results support the hypothesis that the characteristics of the library, including its collection and support services, constitute only one factor, and 
perhaps not even the most important factor, influencing use; the student's personal characteristics and program of study must also be considered. For instance, students with higher levels of educational achievement prior to their taking continuing education courses as well as older students used university library services less often than others: these students may have developed alternative means of meeting their learning needs or they may have become frustrated and simply given up trying. This emphasizes the importance of systematically documenting and assessing user characteristics and needs as student populations become more diverse.

The data also suggest the substantial impact of the student's program of study on patterns of university library use. Students in part-time degree programs had substantially higher rates of use than those in non-degree programs and students in full-time programs used library services most often. In part this difference is a function of relative levels of need for and access to library services: full-time students take more courses than others during a semester and they typically spend more time on campus close to the university library. However, differences in patterns of use also substantially reflect what goes on in the classroom. In courses in which students had assignments which required library use or in which they were introduced to the library through formal orientations or in-class discussion, rates of use were significantly higher. This emphasizes the role of curriculum in different programs and fields of study which may place variable emphasis on knowledge acquired through library research. It points also to the role and characteristics of individual instructors who design and deliver curriculum but who may be more or less familiar not only with the library but with academic research skills. Particularly in continuing education where instructors have often not been acknowledged as full members of the university community, there has been little systematic support to develop their knowledge and skills in areas related to their teaching; for instance, few will have had a formal orientation to the university library. The general culture of the university may also play an important role: an historic tendency to relegate small undergraduate universities, including the one in which this study was conducted, to teaching with heavy faculty teaching loads and student contact hours may result in an underdeveloped research culture, and teaching and learning which do not integrate library use (Owen, 1992; Schlichter \& Pemberton, 1992). Such factors clearly must be taken into account when trying to assess the role of the academic library and strategies for enhancing its contribution to learning.

The suggestion that the university library must be conceptualized and planned within the context of user characteristics and the broader learning environment is 
consistent with a recent study of library use by students in three Ontario medical schools. This study found that students in problem-based programs used the library more frequently, for longer periods of time, and as a source of a greater proportion of their study materials than students in more traditional programs; the researchers concluded that such differences could not be accounted for by differences in library collection, physical location, or staffing (Marshall et al., 1993). Surveys, as well as other methods of collecting information about users, clearly must go beyond the conventional focus on adjustments to library hours and holdings to analyzing user needs, and ways in which those needs can be addressed (Gothberg, 1990). As Miksa suggests, key questions should focus not on the collection but on ways of "interpreting, applying, manipulating and producing information" relevant to the user (1989, p. 786).

There are obvious limits to this analysis; for instance, the data cannot comment on the relative "quality" or productivity of reported academic library uses and whether some uses for students under certain conditions may be more valuable than others. They also raise but fail to address issues of student capabilities, curriculum design and instructor qualifications. However, this does not detract from but rather emphasizes the relevance and importance of developing a broad conceptual understanding of the academic library which can integrate such issues and elaborate the role of the library in addressing them. Even though the collection is likely to remain a core feature of the academic library, it is important to ask how the collection along with the increasing range of information services available will serve user needs in a rapidly changing learning environment.

\section{References}

Berry, J.W. (1985). Academic reference departments and user groups: A preliminary survey. Reference Librarian, 12, 5-16.

Brody, L. (1989). The future of reference II: A response. College and Research Libraries, 50(9), 794-796.

Gothberg, H.M. (1990). The library survey: A research methodology rediscovered. College and Research Libraries, 51(6), 553-559.

Kopplin, W. (1989). The future of reference II: Discussion summary. College and Research Libraries, 50(9), 796-799.

Marshall, J.G., Fitzgerald, D., \& Busby, L. \& Heaton, G. (1993). A study of library use in problem-based and traditional medical curricula. Bulletin of the Medical Librarians Association, 81(3), 299-305.

Malone, C.K. (1989). The future of reference II: A response. College and Research Libraries, 50(9), 790-793.

Miksa, F. (1989). The future of reference II: a paradigm of academic library organization. College and Research Libraries, 50(9), 780-790. 
Owen, M. (1992). Research at small Canadian universities. The Canadian Journal of Higher Education, 22(2), 1-14.

Phillips, L.L., \& Lyons, W. (1990). Analysing library survey data using factor analysis. College and Research Libraries, 5I(5), 483-489.

Schlachter, G., \& Belli, D. (1976). Program evaluation-an alternative to divine guidance. California Librarian, 37, 26-31.

Schlichter, D.J., \& Pemberton, J.M. (1992). The emperor's new clothes? problems of the user survey as a planning tool in academic libraries. College and Research Libraries, 53(3), 257-265.

Statistics Canada. (1994). Education Quarterly Review, 1(4), 59, 76.

Zweizig, D.L. (1976). With our eye on the use: needed research for information and referral in the public library. Drexel Library Quarterly, 12, 48-58.

\section{Appendix A}

\section{Exact Wording of Questionnaire Items Employed in the Analysis}

\section{Table 1}

About how many times during the current academic term (Winter 1992) have you used university or public libraries other than [this university's] for course related work?

About how many times during the current term have you used [this university's]

Library?

Table 2

About how many times have you used each of the following Library services [at this university] during the current term?

- study areas

- photocopiers

- borrowing books
- periodicals/magazines/newspapers

- staff assistance

- reserve collection

$\underline{\text { Table } 3}$

Are you ...

- female - male

Is English your first language, the one you learned first?

What was the highest level of education you had completed before beginning your current studies at [this university]?

- less than high school graduation

- high school graduation

- community college certificate or diploma

- certificate or diploma [at this university]

- university degree

What was your age on March 11992 ? 
Table 4

Which best describes the type of program in which you are currently enrolled?

- individual course only

- academic bridging course (ABC)

- part-time degree

- certificate

Which one response best describes your current field of study at [this university]?

- Arts (eg. social sciences, languages)

- Applied Arts (eg. architecture, design)

- Business

- Community Services

- Engineering and Applied Sciences

How many of the assignments in this course involve reading or research outside of the course lectures, textbook and notes?

Have you ever received an orientation to Library services [at this university] from Library staff?

Has your instructor in this course ever discussed Library services [at this university] in connection with your course work?

\section{Table 5}

In your own experience as a CE student, how important is each of the following as a factor limiting your use of the [this university's] Library.

- inadequate collection

- materials locked and inaccessible on evenings and weekends

- inappropriate hours

- lack of Library staff

- don't know how to use the Library

- don't know how to get a Library card

\section{Appendix B}

\section{Construction of Multple Item Scale of Library Use}

The multiple item variable used in the analysis measures, for each respondent, total use of the study areas, xerox, book collection, periodicals, staff assistance and the reserve collection during the previous semester (see Appendix A for exact wording). Because they had frequencies close to zero, 3 other survey items measuring use of the audio-visual collection, CD ROM and inter-library loans were not included. Factor analysis confirmed the dimensionality of the 6 selected variables: the first principal component produced an eigenvalue of 4.51 and accounted for $61 \%$ of the total variance. Variable scores were then computed by summing scores on the individual component items. The consensus in the methodological literature is that unless component items differ appreciably in variance, the simple sum approximates the reliability of a score computed using factor weights. These simple scores have the advantage of greater intelligibility. 